\title{
Three probable cases of cutaneous anthrax in autonomous province of Vojvodina, Serbia, June 2011
}

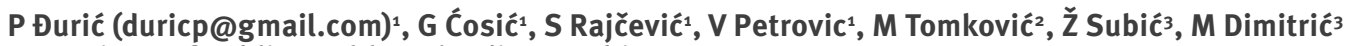

1. Institute of Public Health, Vojvodina, Serbia

2. Institute of Public Health, Kikinda, Serbia

3. Institute of Public Health, Zrenjanin, Serbia

Citation style for this article:

Đurić P, Ćosić G, Rajčević S, Petrovic V, Tomković M, Subić Ž, Dimitrić M. Three probable cases of cutaneous anthrax in autonomous province of Vojvodina, Serbia, June 2011.

Euro Surveill. 2012;17(1):pii=20050. Available online: http://www.eurosurveillance.org/ViewArticle.aspx?Articleld=20050

Article published on 5 January 2012

Three probable cases of cutaneous anthrax were reported in June 2011 in the eastern part of the Autonomous Province of Vojvodina, Serbia. All cases were involved in slaughtering of a heifer that died and was suspected to have had anthrax. In the same village, anthrax was confirmed in other animals.

\section{Introduction}

Anthrax is an acute bacterial infection caused by the aerobic, spore-forming, Gram-positive organism Bacillus anthracis, found throughout the world. It is primarily an animal disease that occurs in wild and domestic livestock (such as cattle, sheep and goats) and rarely affects humans under normal circumstances. Humans can acquire anthrax by exposure to infected animals, animal products or spores in the soil and depending on the mode of transmission can develop one of four distinct clinical forms: cutaneous, respiratory, gastrointestinal and oropharyngeal [1].

The cutaneous form of disease is involved in $95 \%$ of human cases but the diagnosis can be very difficult in atypical presentations and in non-endemic regions when rarely encountered in clinical practice. Any delay in treatment, especially in systemic anthrax, may have fatal consequences, illustrated by case reports [2-4].

Anthrax spores and bacilli are present in the soil in some countries in Europe and continue to cause disease in animals and, occasionally, humans. In the middle and northern latitudes of Europe, anthrax in animals is either absent or found only in sporadic cases, while it remains relatively common in Turkey, Greece, the Balkan countries, Italy, Spain and the Russian Federation [5]. Given the proximity of the neighbouring countries in which human cases of confirmed anthrax have recently been found (Bosnia and Herzegovina, Bulgaria, Croatia and Romania) and uncontrolled transport of cattle across the border is very possible that there would be new cases of disease [6-9].

In Serbia anthrax occurs sporadically in animals and rarely in humans. During last five years, only five human cases were reported: four in 2008 and one in 2009 [10]. Human anthrax has been well known in the Autonomous Province of Vojvodina (APV) before 1988, a region of flat land in the north of Serbia where animal husbandry is one of the primary occupations. According to the Institute of Public Health of Vojvodina, human anthrax occurred after the Second World War with an incidence of 0.05 to 8.59 per 100,000 population [11]. The last case of human anthrax that occurred in the APV before 2011 was reported in 1988 [12].

We describe here cases of anthrax that occurred in humans and animals in Bocar, APV, in June 2011. Further cases among animals were also registered in early November 2011 in eastern Serbia, near the city of Pirot, close to the border of Bulgaria.

\section{Anthrax in animals}

In a household in the village of Bocar (Household $A$ ) in the north-eastern part of the APV, one heifer died on 2 June 2011. This death was not recognised at the time as caused by anthrax and was not reported to the veterinary authorities. The heifer was butchered in another household (Household B) on the next day.

A routine investigation of the unexplained death of the heifer took place four days later, on 6 June 2011 by the veterinary institute and veterinary centres of the two districts Zrenjanin and Kikinda, as Bocar is situated on the border of these districts. The veterinary inspection detected another two sick animals (horse and heifer) in Household A. Samples were taken from the ear muscles of those two animals. The presence of $B$. anthracis was established on 7 June by deep isolation agar and Ascoli precipitin test [13].

In Household B, a goat died on 19 June. The presence of $B$. anthracis was confirmed in a tissue sample. In another village Novo Milosevo, about 10 kilometres away from Bocar, a sick cow was reported on 17 June, which subsequently died on 22 June, with microbiologically confirmed anthrax. 
Clinically ill animals have fever, difficulty in breathing, with bloody discharges from natural openings in the heifer. The animals died within two or three days after beginning of symptoms. Common to all ill animals was that they were pastured in areas recently covered with high groundwater. The dead animals had not been vaccinated against anthrax.

\section{Human cases of anthrax}

From 5 to 9 June 2011, cutaneous anthrax was diagnosed in three workers who were in contact with the first dead heifer during slaughter, and had not had any contact to the other sick animals. They were classified as probable cases of anthrax based on epidemiological and clinical data. Skin manifestation occurred on the patients' hands after the incubation period of one to two days [13], followed by high fever, without any other symptoms. The infection started as a pruritic papula. In two days the papula enlarged and formed an ulcer, about $2 \mathrm{~cm}$ in diameter, with typical black central crust. There was oedema of the ulcer and surrounding skin. The skin lesions were painless. The patients were treated with antibiotic therapy 15 days at home and recovered. No laboratory diagnostic tests were done on the human patients.

A further five persons who had been exposed to dead animals were followed up for 24 days during the incubation period, but no clinical signs and symptoms appeared. No human deaths were reported in the area in that period which that could have been due to undiagnosed anthrax. Meat from infected animals was not consumed because the carcasses were destroyed after appropriate transport. The meat from the first slaughtered heifer was not available for investigation and may have been used to feed pets.

\section{Control measures}

After the outbreak was reported following the death of the second animal, the veterinary authorities ordered control measures:

- a ban on releasing animals from the infected pastures for the duration of the outbreak and the risk of spread (six weeks),

- a ban on the slaughter of sick animals,

- prohibition of the use of milk and dairy products, or meat, skin and other products, as well as the sale of animals with clinical manifestation of illness or suspected to infection,

- vaccination of cattle, sheep, goats and Equidae,

- prohibition of butchering of dead and sick animals,

- disinfection of places where a dead animal had been kept.

The population of affected areas was encouraged to report all animal deaths to the veterinary authorities, to treat carcasses of dead animals only in accordance with the instructions of experts, to limit the number of persons present in contaminated yards, to use protective equipment in contact with the animals and to disinfect it after use, and to contact a medical service immediately in case they developed fever or skin changes. Educational material about anthrax was distributed to households in affected areas.

\section{Discussion}

Currently, very few cases of anthrax occur in developed countries [14], but in developing countries anthrax continues to be an important infectious disease. The incidence of infection can be reduced dramatically by the vaccination of animals at high risk, along with improvements in industrial hygiene [15]. In Serbia routine vaccination of livestock against anthrax is not implemented regularly but is carried out only in areas where this bacterium is present in the soil and nature.

The three probable human cases of anthrax in Bocar we describe here could be a result of feeding cattle with hay and grass on pastures which had high ground water following heavy rains during spring. Several studies have shown that meteorological factors such as shifts between rainy and dry periods can contribute to the migration of anthrax spores on the surface of pasture land and contamination by anthrax spores [1620]. Under adverse environmental conditions, e.g. after release into soil from dead or dying animals, the vegetative bacilli die but endospores survive. The spores are remarkably resistant to a range of adverse environmental conditions such as temperature, desiccation, $\mathrm{pH}$, chemicals or irradiation, which makes decontamination difficult.

As anthrax spores can persist for a long time in the environment, decontamination of the ground and vaccination of animals are important public health measures to prevent further cases in animals and humans and they should be continued even after several anthrax-free years. Existing programmes of prevention and control of both animal and human anthrax need to be evaluated and the surveillance system enhanced, including the development of laboratory diagnostic capacities for human anthrax in Serbia. The enhanced surveillance system requires close collaboration between services for the prevention and control of human and animal diseases, and prompt reaction of both services after reports of possible cases of anthrax.

\section{References}

1. Centers for Disease Control and Prevention (CDC). Fact sheet: anthrax information for health care providers. Atlanta: CDC. [Accessed 2 Dec 2011]. Available from: http://emergency.cdc. gov/agent/anthrax/anthrax-hcp-factsheet.asp

2. Chraibi H, Haouach K, Azouzi Al, Gaamouche K, Kaidi TE, Khalidi TE, et al. Cutaneous anthrax: seven cases. French. Ann Dermatol Venerol. 2009;136(1):9-14.

3. Caugrant DA, Fossum K, Hoel T, Høiby EA, Iversen BG, Jensenius $M$, et al. Systemic anthrax in an injecting drug user: Oslo, Norway April 2000. Euro Surveill. 2000; 4(19):pii=1605. Available from: http://www.eurosurveillance.org/ViewArticle. aspx?Articleld $=1605$

4. Ramsay CN, Stirling A, Smith J, Hawkins G, Brooks T, Hood J, et al. An outbreak of infection with Bacillus anthracis in injecting drug users in Scotland. Euro Surveill. 2010;15(2):pii=19465. Available from: http://www.eurosurveillance.org/ViewArticle. aspx?Articleld $=19465$ 
5. Schmid G, Kaufmann A. Anthrax in Europe: its epidemiology, clinical characteristics, and role in bioterrorism. Clin Microbiol Infect 2002;8(8):479-88.

6. Croatian Institute for Public Health HZIZ). Izvješće o radu službe za epidemiologiju zaraznih bolesti u 2010. [Annual report of the Service for the epidemiology of communicable diseases for 2010]. Zagreb: HZJZ; March 2001. Croatian. Available from: http://www.hzjz.hr/epidemiologija/izvjesce1o. pdf

7. Institute of Public Health of Bosnia and Herzegovina. Epidemiološka situacija na području Federacije bosne i hercegovine U 2010. [The epidemiological situation in the Federation of Bosnia and Herzegovina in 2010]. Epidemiological bulletin 18(29). Sarajevo/Mostar: Institute of Public Health FB\&H, 2011. Bosnian. Available from: http:// www.zzjzfbih.ba/wp-content/uploads/2010/02/Epidemioloskibilten-29-god-2010.pdf

8. European Centre for Disease Prevention and Control (ECDC). Annual epidemiological report on communicable diseases in Europe 2010. Stockholm: ECDC; 2010. Available from: http:// www.ecdc.europa.eu/en/publications/Publications/1011 SUR_Annual_Epidemiological_Report_on_Communicable Diseases_in_Europe.pdf

9. Popescu R, Pistol A, Militaru L, Caplan D, Cucuiu R, Popovici F. Two cases of infection with Bacillus anthracis, Romania, October 2011. Euro Surveill. 2011;16(45). Available from: http:// www.eurosurveillance.org/ViewArticle.aspx?Articleld $=20008$

10. Institute of Public Health of Serbia. Report on communicable diseases in the Republic of Serbia in 2010. Serbian. Belgrade: Institute of Public Health of Serbia; 2011. p. 26.

11. Institute of Public Health of Vojvodina. Communicable diseases in Vojvodina, 2010. Annual report. Serbian. Novi Sad: Institute of Public Health of Vojvodina; 2010. p. 23.

12. Institute of Public Health of Vojvodina. Communicable diseases in Vojvodina, 1988. Annual report Serbian. Novi Sad: Institute of Public Health of Vojvodina; 1989. p. 93-4.

13. World Health Organisation (WHO). Anthrax in humans and animals. Fourth edition. Geneva: WHO; 2008. ISBN 978924 154753 6. Available from: http://www.who.int/csr/resources/ publications/AnthraxGuidelines2008/en/index.html

14. Inglesby TV, Henderson DA, Bartlett JG, Ascher MS, Eitzen E, Friedlander AM, et al. Anthrax as a biological weapon: medical and public health management. JAMA 1999;281(18):1735-45.

15. Dixon TC, Meselson M, Guillemin J, Hanna PC. Anthrax. N Engl J Med 1999;341(11):815-26.

16. Dragon D, Rennie PR. The ecology of anthrax spores: tough but not invincible. Can Vet J. 1995; 36(5):295-301.

17. Turnbull P, Lindeque M, Le Roux J, Bennet M, Parks S. Airborne movement of anthrax spores from carcass sites in the Etosha National Park, Namibia. J. Appl Microbiol. 1998;84(4):667-76.

18. Turner A, Galvin J, Rubira RJ, Condrom RJ, Bradley T. Experiences with vaccination and epidemiological investigations on an anthrax outbreak in Australia in 1997. J Appl Microbiol. 1999;87(2):294-7.

19. Kreidl P, Stifter E, Richter A, Aschbachert R, Nienstedt F, Unterhuber $\mathrm{H}$, et al. Anthrax in animals and a farmer in Alto Adige, Italy. Euro Surveill. 2006; 11(7):pii=2900. Available from: http://www.eurosurveillance.org/ViewArticle. aspx?Articleld $=2900$

20. Titball RW, Turnbull P, Hutson RA. The monitoring and detection of Bacillus anthracis in the environment. Soc Appl Bacteriol Symp Ser. 1991;20:9S-18S. 